\title{
Toprak pH'sını Etkileyen Bazı Materyallerin Hububat Tarımında Kullanımı
}

\author{
Kadir UÇGUN ${ }^{1, *}$ (D) Caner KELEBEK ${ }^{2}$ Murat CANSU³ Mesut ALTINDAL $^{3}$ Bilal YALÇIN ${ }^{3}$
}

\author{
'Karamanoğlu Mehmetbey Üniversitesi Teknik Bilimler MYO, Karaman \\ º̈zel Tarım Danıșmanı-Ulubey, Ușak \\ ${ }^{3}$ Meyvecilik Araștırma Enstitüsü Müdürlüğü, Eğirdir, Isparta
}

\author{
*Sorumlu yazar e-mail (Corresponding author e-mail): kadirucgun@gmail.com \\ Geliș tarihi (Received): 09.07.2019 \\ Kabul tarihi (Accepted): 19.07.2019 \\ DOI: $10.21657 /$ topraksu.655284
}

\section{Öz}

Toprak pH'sı besin elementlerinin yarayıșlılığını etkileyen en önemli faktörlerden biri olup hububat yetiștiriciliğinin yoğun olarak yapıldığı Orta Anadolu'nun tarım alanlarında yüksek düzeylerdedir. Yüksek olan toprak pH'sının düșürülmesi için piyasada birçok ürün bulunmaktadır. Bu çalıșma 2016 yılında yapılmıș ve bazı ürünlerin toprak pH'sı üzerine etkileri incelenmiștir. Ușak ilinin Ulubey ilçesinde arpa yetiștiriciliği yapılan bir tarım arazisinde 4 farklı uygulama (Kontrol, Sulu Kükürt, Bentonitli Kükürt + Çiftlik Gübresi, Leonardit) ekimle birlikte yapıımıștır. Bitki gelișimin aktif ve hızlı olduğu Mart, Nisan ve Mayıs aylarının ortasında (3 dönemde) $0-20 \mathrm{~cm}$ derinliğinden toprak örnekleri alınarak bu topraklarda EC ve $\mathrm{pH}$ ile bitkiye yarayıșlı $\mathrm{Fe}, \mathrm{Cu}, \mathrm{Mn}$ ve $\mathrm{Zn}$ analizleri yapılmıștır. Hasat zamanında ise bașak örnekleri alınarak tanelerin besin elementi içerikleri belirlenmiștir. Varyans analizleri göre yapılan uygulamaların Mart ve Nisan ayında alınan toprakların pH'sı üzerine etkisi olmamıș fakat Mayıs ayının ortasında alınan topraklarda önemli bir etkinin olduğu tespit edilmiștir. Bentonitli Kükürt + Çiftlik Gübresi uygulamasının yapıldığı parselde en düșük pH değerleri elde edilirken diğer ürünlerin uygulandığı parsellerden daha yüksek ve birbirine yakın sonuçlar elde edilmiștir. pH'nın düșük olduğu parsellerde bitkiye elverișli Fe ve $\mathrm{Mn}$ değerlerinin yüksek olduğu görülmüștür. Uygulamalarının bașakların N, P, K, Mg ve Fe içeriği üzerine etkisi istatistiksel olarak önemli olmuș ve Mg hariç diğerlerinde Bentonitli Kükürt + Çiftlik Gübresi uygulamasından en yüksek değerler elde edilmiștir.

Anahtar kelimeler : Arpa, besin elementi, kükürt, leonardit, pH

\section{Using of Some Materials Affecting Soil pH in Cereal Cultivation}

\begin{abstract}
Soil $\mathrm{pH}$ is one of the most important factors affecting the availability of nutrients and is high in the agricultural areas of Central Anatolia where cereal cultivation is intensively done. There are many products on the market to reduce the high soil $\mathrm{pH}$. This study was carried out in 2016 and the effects of some products on soil pH were investigated. 4 different applications (control, liquid sulfur, sulfur with bentonite + manure, leonardite) were carried out simultaneously with sowing in an agricultural field where barley cultivation in Ulubey district of Ușak province. Soil samples were taken from 0-20 cm soil depth in the middle of March, April and May (3 periods) in which plants growing is active and speed and $\mathrm{EC}, \mathrm{pH}$ and available $\mathrm{Fe}, \mathrm{Cu}, \mathrm{Mn}$ and $\mathrm{Zn}$ were determined in collected soils. At harvest time,
\end{abstract}


grain samples also were taken and nutrient contents were determined. According to variance analysis, It was determined that the treatments did not have an effect on the $\mathrm{pH}$ of the soil taken in March and April but it was found to be an important effect in the soil taken in the middle of May. The lowest $\mathrm{pH}$ values were obtained from sulfur with bentonite + manure, while the other products had higher and closer results each other. Fe and Mn values were found to be higher in the soil where $\mathrm{pH}$ was low. The treatments were statistically important on the $\mathrm{N}, \mathrm{P}, \mathrm{K}, \mathrm{Mg}$ and Fe content of the grains except $\mathrm{Mg}$ and the highest values were obtained from the applications of sulfur with bentonite + manure.

Keywords: Barley, leonardite, nutrient, pH, sulfur

\section{Gíriș}

Türkiye topraklarının büyük bölümünün pH'sı 7'nin üzerinde olup kireç içerikleri de yüksektir (Gücdemir, 2006). Toprak pH'sı asitlik $(\mathrm{pH}<7)$ ve alkaliliğin $(\mathrm{pH}>7)$ bir ölçüsüdür. Asit topraklar yüksek oranda $\mathrm{H}^{+}$iyonlarına sahip iken alkali topraklar düșük $\mathrm{H}^{+}$iyonlarına sahiptir (Anonymous, 2013). Toprak pH'sı logaritmik bir özellik olduğu için her bir birim diğerinden 10 kat daha fazla yada daha az asidiktir. Örneğin pH'sı 6.0 olan bir solüsyonda $\mathrm{pH}$ 'sı 7.0 olana göre 10 kat daha fazla $\mathrm{H}^{+}$iyonları bulunmaktadır Toprak $\mathrm{pH}^{\prime}$ sı hem asit $\left(\mathrm{H}^{+}, \mathrm{Al}^{+3}, \mathrm{Fe}^{+2}, \mathrm{Fe}^{+3}\right.$, ) hem de baz $\left(\mathrm{Ca}^{+2}, \mathrm{Mg}^{+2}, \mathrm{Na}^{+}\right)$formundaki katyonlardan da etkilenmektedir. (McCauley vd., 2017).

Organik madde ve $\mathrm{pH}$, toprak özelliklerini ve bitki besin elementlerinin yarayıșlıığını güçlü bir șekilde etkilemektedir. Bir toprağın besin elementlerini tutması ve bitkiye sunması katyon ve anyon değișim kapasitesi ile ilgilidir. Katyon ve anyon değișim kapasitesi toprak $\mathrm{pH}^{\prime}$ sı tarafından etkilenir. Kil ve organik madde miktarı yüksek olan toprakların katyon değișim kapasiteleri ve tamponlama kapasitesi yüksektir. Toprak pH'sı bitki besin elementlerin yarayıșılıı̆ını etkiler çünkü negatif yüzeylerde $\mathrm{H}^{+}$iyonları tutulmaktadır. Besin elementinin bitkiler tarafından alınabilirliği molekülün boyutuna ve değerliğine bağlıdır. Cu, $\mathrm{Mn}, \mathrm{Fe}, \mathrm{Zn}$ gibi metal özellikte besin elementleri suda çözündüğü zaman +2 veya +3 değerlikli olmaktadır. Bu yüzden $\mathrm{H}^{+}$iyonlarının az olduğu alkali ortamlarda toprak partikülleri tarafından kuvvetli bir șekilde tutularak bitkiler tarafında alımı zorlașmaktadır. Kükürt ve baz karakterli $\left(\mathrm{Ca}^{+2}, \mathrm{Mg}^{+2}\right.$, $\mathrm{Na}^{+}$) katyonlar nispeten büyük molekül yapısına sahip olduğundan toprak zerrelerinin yüzeyine kolaylıkla yapıșamaz ve toprak solüsyonunda bitkilerin alabileceği formlarda bulunur (McCauley vd., 2017). Bir besin elementi köklere girinceye kadar toprak solüsyonunda bașarılı bir șekilde hareket edebilmesi için yeterince uzun süre ve çözünmüș halde toprak solüsyonunda bulunmalıdır (Vossen, 2017). Genelde toprak pH'sının N, K, Ca, Mg ve S için 6.5-8.0, B, Cu, Fe, $\mathrm{Mn}, \mathrm{Ni}$ ve $\mathrm{Zn}$ için 5.0-7.0 ve $\mathrm{P}$ için 5.5-7.5 olması istenir. $\mathrm{pH}$ 5.5'in altına düștüğünde Al ve Mn'nin seviyesi bitkilere toksik olacak düzeylere ulașabilir (McCauley vd., 2017; Anonymous, 2013).

Toprak pH'sı bitkiler için gerekli elementleri içeren mineral kayaların ayrıșması için çok önemli bir toprak özelliğidir. Ayrıca toprak pH'sı kullanılan gübrelerin bitkilerin kullanabileceği formlara dönüșmesini de etkiler. Örneğin toprak mikroorganizmaları amino asit formunda bulunan N'un amonyum ve nitrat formlarına dönüșmesini sağlar (Vossen, 2017). Bu yüzden mikroorganizma faaliyetleri, bitki gelișimi ve besin elementlerinin alınabilirliği yönünden toprak pH'sının 6.5-7.5 arasında olması arzu edilir (McCauley vd., 2017; Anonymous, 2013).

Toprak pH'sının ayarlanmasında kükürt (elementel kükürt, demir sülfat, alüminyum sülfat), kireç, kimyasal gübreler ve organik madde etkili olmaktadır (McCauley vd., 2017; Güneri vd., 2012). Toprak pH'sının düșürülmesinde en ucuz yol toprağa elementel kükürt kullanılmasıdır. Çeșitli yollar ile toprağa karıșan kükürt bir seri tepkimelerle dönüșüme uğramaktadır (Kaymak, 2011). Elementel kükürt toprak bakterileri tarafından sülfürik asite dönüștürülür. Bu asit ise toprak PH'sının düșmesine yardımcı olur. Demir sülfat, toprak $\mathrm{pH}$ 'sı üzerine etkili materyallerden biridir. Fakat elementel S'ye göre 8 kat daha fazla kullanılmalıdır. Bu yüzden çok maliyetlidir. Demir Sülfat reaksiyonu çok hızıdır ve bu tuzlar Fe ve $\mathrm{H}_{2} \mathrm{SO}_{4}^{\prime}$ 'e ayrıșır. Aluminyum sülfat toprakları asitleștiren diğer bir materyaldir. Fakat yüksek miktarlarda uygulandığında Al bitkiler üzerine toksik etki yapmaktadır. Damla sulama siteminin kullanılabildiği yetiștirme sistemlerinde sıvı asitler de bu amaçla kullanılmaktadır (Longstroth, 2017). 
Çiftlik gübresinin $\mathrm{pH}$ üzerine etki yapma kabiliyeti içindeki çeșitli maddelerin miktarına bağlıdır. Çiftlik gübresi toprağa uygulandığı zaman ayrıșma ve nitrifikasyon olayları ile çeșitli asitler üretilir. Nitrifikasyon, amonyumun nitrata toprak mikroorganizmaları tarafından dönüștürülmesi ișlemidir. Bu ișlem sırasında toprak solüsyonuna $\mathrm{H}^{+}$iyonları serbest bırakılır. Organik maddenin ayrıșması sırasında organik asitler ve karbonik asit ortaya çıkar (Chang vd., 1991). Ciftlik gübrelerinin SIVı kısmı ve kanatlı hayvanların gübreleri yüksek oranda $\mathrm{NH}_{4}$ formunda $\mathrm{N}$ ve düșük oranda organik madde içerdiğinden $\mathrm{NH}_{4}$ formundaki sentetik gübreler gibi daha düșük $\mathrm{pH}$ değerine sahip olabilirler (Anonymous, 2013). Torf gibi bazı organik materyaller de zamanla torak pH'sını düșmesini sağlar fakat doğada bu olay binlerce yılda olușur (Mickelbart vd., 2017; Vossen, 2017). Toprak pH değerinin düșürülmesinde toprak uygulamalarının dıșında sitrik asit uygulamalarından da yararlanılmaktadır (Patel vd., 1997).

Yapılan bu çalıșma ile bitki gelișimini olumsuz etkileyen yüksek $\mathrm{pH}$ değerlerinin ayarlanmasında etkili olduğu düșünülen bazı materyallerin arpa tarımı yapılan bir arazide toprakların $\mathrm{pH}$, EC ve mikro element değerleri ile bașak tanelerinin bitki besin elementi içeriği üzerine etkisi incelenmiștir.

\section{MATERYAL VE METOT}

Bu çalıșma 2016 yılında Ușak ilinin Ulubey ilçesinde kuru tarım arpa (Çakır) yetiștiriciliği yapılan bir arazide sulu kükürt (SK), bentonitli kükürt (BK)+çiftlik gübresi (ÇG), Leonardit (L) ve Kontrol $(\mathrm{K})$ uygulamalarının bazı toprak ve bitki parametreleri üzerine etkisi araștırılmıștır. Uygulamalar ekimle birlikte 2015 yılının Kasım ayında yapılmıștır. Dekara SK 4 litre $(6 \mathrm{~kg})$, BK $50 \mathrm{~kg}$, Ç 4 ton ve L $50 \mathrm{~kg}$ olarak kullanılmıștır. Tüm parsellere ekimle birlikte dekara $15 \mathrm{~kg}$ DAP gübresi uygulanmıștır. Bitki gelișimin aktif olduğu zaman aralığında 3 dönemde 15 Mart, 15 Nisan ve 15 Mayıs) toprak örnekleri alınarak Elektriksel iletkenlik (EC), toprak reaksiyonu $(\mathrm{pH})$, ekstrakte edilebilir demir (Fe), bakır $(\mathrm{Cu})$, mangan (Mn) ve çinko (Zn) analizleri yapılmıștır. Hasat döneminde alınan bașakların taneleri çıkartılarak azot $(N)$, fosfor $(P)$, potasyum $(K)$, kalsiyum (Ca), magnezyum (Mg), Fe, Cu, Mn ve $\mathrm{Zn}$ içerikleri belirlenmiștir. Bitki örnekleri 65 'C'de sabit ağırlığa gelinceye kadar kurutulmuș ve $0.5 \mathrm{~mm}$ elek çapına sahip değirmende öğütülmüștür. Azot analizi için kjeldahl yaș yakma metodu, diğer besin elementlerinin analizi için kuru yakma uygulanmıș ve okuma ICP-OES (Inductively Coupled Plasma Atomic Emission Spectophometer) cihazı ile yapılmıștır (Ryan vd., 20011 .

Çizelge 1. Uygulamaların toprakların bazı özellikleri üzerine etkisi

Table 1. Effect of treatments on some properties of soil

\begin{tabular}{|c|c|c|c|c|c|c|c|}
\hline Uygulama & Dönem & $E C\left(\mathrm{dS} \mathrm{m}^{-1}\right)$ & $\mathrm{pH}$ & $\mathrm{Fe}(\mathrm{ppm})$ & $\mathrm{Mn}$ (ppm) & $\mathrm{Cu}$ (ppm) & $\mathrm{Zn}$ (ppm) \\
\hline SK & \multirow{4}{*}{1} & 0.54 & 7.74 & 1.01 & 1.27 & 0.23 & 0.59 a \\
\hline $\mathrm{BK}+\mathrm{CG}$ & & 0.56 & 7.88 & 1.06 & 1.40 & 0.22 & $0.44 \mathrm{~b}$ \\
\hline L & & 0.52 & 7.83 & 1.04 & 0.91 & 0.22 & $0.31 \mathrm{~b}$ \\
\hline K & & 0.59 & 7.85 & 0.98 & 1.18 & 0.21 & $0.37 \mathrm{~b}$ \\
\hline P değeri & & Ö.D & Ö.D & Ö.D & Ö.D & Ö.D & $P<0.01$ \\
\hline SK & \multirow{4}{*}{2} & 0.49 & 7.74 & 1.16 & 0.85 & 0.18 ab & $0.44 a$ \\
\hline $\mathrm{BK}+\mathrm{CG}$ & & 0.58 & 7.73 & 0.78 & 0.75 & $0.13 \mathrm{~b}$ & $0.21 \mathrm{~b}$ \\
\hline L & & 0.60 & 7.71 & 1.10 & 0.83 & 0.19 a & $0.29 \mathrm{ab}$ \\
\hline K & & 0.59 & 7.79 & 1.50 & 0.85 & $0.21 \mathrm{a}$ & $0.32 \mathrm{ab}$ \\
\hline$P$ değeri & & Ö.D & Ö.D & Ö.D & Ö.D & $P<0.05$ & $P<0.05$ \\
\hline SK & \multirow{4}{*}{3} & 0.36 & 7.89 a & 0.83 & $1.18 \mathrm{ab}$ & 0.22 & $0.48 a$ \\
\hline $\mathrm{BK}+\mathrm{CG}$ & & 0.40 & $7.79 \mathrm{~b}$ & 1.34 & $1.42 \mathrm{a}$ & 0.23 & $0.25 \mathrm{~b}$ \\
\hline $\mathrm{L}$ & & 0.43 & 7.92 a & 1.20 & $1.02 \mathrm{~b}$ & 0.23 & $0.32 \mathrm{~b}$ \\
\hline K & & 0.41 & $7.89 \mathrm{a}$ & 1.10 & $1.10 \mathrm{~b}$ & 0.24 & $0.35 \mathrm{ab}$ \\
\hline P değeri & & Ö.D & $P<0.05$ & Ö.D & $P<0.05$ & Ö.D & $P<0.05$ \\
\hline
\end{tabular}

SK: sulu kükürt, BK: bentonitli kükürt, ÇG: çiftlik gübresi, L: leonardit, K: kontrol 
İstatistik analizler için paket program (JMP) kullanılmıștır. Bu paket program ile normal dağıım analizi yapıımıș ve ekstrem değerler atımıștır. Varyans analizleri yapılarak uygulamalar arasındaki farklııık önemli olduğu durumlarda LSD çoklu karșılaștırma testi uygulanmıștır. İstatistiksel farklılıkların tahmin edilmesinde $P<0.05$ ve $P<0.01$ önem dereceleri kullanıımıștır. Çalıșmada kullanılan ürünlerin içerikleri birbirinden farklı olduğundan varyans analizi ile birlikte "tek serbestlik dereceli analiz" (kontrast analizi) yapılımıștır. Bu analiz ile her bir uygulama ferdi olarak kontrol ile karșılaștırılmıș ve kontrole göre istatistiksel olarak önemli olup olmadığı belirlenmiștir.

\section{BULGULAR VE TARTIȘMA}

Çalıșma kil, silt ve kum içeriği sırasıyla \%30, \%23 ve \%47 olan kumlu killi tın bir toprak yapısına sahip bir arazide yürütülmüștür. Denemenin yürütüldüğü bu arazinin çok fazla kireçli (\%48; Ülgen ve Yurtsever, 1995), organik madde miktarının az (\%1.50; Ülgen ve Yurtsever, 1995), potasyum (370 ppm; Anonymous, 1990) ve kalsiyum içeriğinin fazla (5070 ppm; Anonymous, 1990) ve magnezyum durumunun ise orta (265 ppm; Anonymous, 1990) olduğu deneme öncesi alınan toprak örneklerinde tespit edilmiștir. 2016 yılı arpa yetișme sezonu için kurak bir yıl olmuș ve elde edilen verim değerleri yapılan çiftçi görüșmelerinde önceki yıllara göre düșük olduğu anlașılmıștır. Dekara K'dan 200 kg, L'den 260 kg, BK+ÇG uygulamasından 260 kg. SK uygulamasından $190 \mathrm{~kg}$ verim değerleri elde edilmiștir. L uygulamasının yapıldığı parsele bașaklanma döneminde yapraktan hümik asit uygulaması yapılmıș ve bu uygulamanın bitki gelișimini olumlu yönde etkilediği gözlemlenmiștir. Bitki gelișimi üzerine olumlu olan bu etkinin verime de yansıdığı düșünülmektedir.

Her 3 dönemde alınan toprakların EC değerleri uygulamalara göre istatistiksel olarak önemli bir değișim göstermemiștir. 1. dönemde ortalama 0.55 dS $\mathrm{m}^{-1}$ EC olan değeri 2 ve 3 . dönemde sırasıyla 0.57 ve $0.40 \mathrm{dS} \mathrm{m}^{-1}$ olarak ölçülmüștür. Her bir uygulama kontrole göre ayrı ayrı olarak karșılaștıııldığında 3. dönemde SK uygulamasında ölçülen EC değerinin düșük olduğu ve bu farklılığın \%5 seviyesinde önemli olduğu görülmektedir (Çizelge 1). Her dönemde ölçülen pH değerleri ise ortalama olarak sırasıyla $7.82,7.74$ ve 7.87 olmuștur. Genel olarak EC ve $\mathrm{pH}$ arasında ters bir ilișki bulunmuș yani pH değeri düștüğü zaman EC değerinde yükselme olduğu görülmüștür. Mohd-Aizat vd. (2014), toprak pH'sının düșmesi ile toprakta $\mathrm{H}^{+}$iyonlarının arttığını ve artan $\mathrm{H}^{+}$ iyonları ise toprak EC değeri üzerine arttırıcı etki yaptığını yaptığı çalıșmalarla ortaya koymuștur. Aynı araștırıcı pH ile EC değeri arasında negatif ve tam lineer olmayan bir ilișkinin olduğunu, çünkü $\mathrm{pH}$ yanında toprak sıcaklığı, toprak nemi, tekstür, porozite ve mineraller gibi faktörlerin de EC üzerine etkili olduğunu belirtmiștir.

$\mathrm{pH}$ değerlerinde uygulamalara göre 1. ve 2. dönemde bir farklılık olmamasına rağmen 3. dönemde bir farklıık yakalanmıș ve ölçülen $\mathrm{pH}$ değerleri arasındaki farklılık ise istatistiksel olarak önemli olmuștur. En düșük değer (7.79) $\mathrm{BK}+C ̧ \mathrm{G}$ uygulamasından elde edilmiș ve diğer uygulamalar aynı grupta yer almıștır (Çizelge 1). Uygulamalar kontrole göre bireysel olarak karșılaștırıldığında da sadece 3. dönemde BK+ÇG uygulaması \%1 düzeyinde kontrole göre daha düșük olduğu tespit edilmiștir (Çizelge 3).

Toprak pH'sının ayarlamasında sık olarak kullanılan SK'nın $\mathrm{pH}$ üzerine etkisi olmadığı görülmüștür. Toprağa uygulanan S'ün etkili olabilmesi için biyolojik bir süreç gerekmektedir. Biyolojik süreç kimyasal süreç gibi hızlı değildir. Bu ișlem bakteriler tarafından gerçekleștirilir. Ayrıca bakteriler toprak nemi ve ısısı uygun olduğu zaman aktif olurlar. Bu yüzden Longstroth (2017), kükürt uygulamalarının ilkbaharda yapııması gerektiğini bildirmiștir. Çünkü sonbaharda yapılan kükürt uygulamalarında toprak bakterileri kıș aylarında aktif olmadığı için bir sonraki ilkbaharda pH üzerine çok az etkisi bulunmaktadır. Yaptığımız çalıșmada yapılan toprak uygulamalarının toprak özellikleri üzerindeki etkisi uygulamadan yaklașık 5 ay sonra ölçülmeye bașlanmıștır. Bu yüzden $S$ uygulamalarının toprak $\mathrm{pH}$ 'sı üzerine beklenen etkisinin olmadığı düșünülmektedir. Chang vd. (1991) organik maddenin $\mathrm{pH}$ üzerine etkili olabilmesi için ayrıșma ișleminin gerçekleșmesi gerektiğini bildirmiștir. Bu ișlem için ise belli zamana intiyaç bulunmaktadır. Ayrıșma sırasında $\mathrm{CO} 2, \mathrm{H}^{+}$ve organik asitler orya çımmaktadır. $\mathrm{H}^{+}$ ve organik asitler toprak $\mathrm{pH}^{\prime} \mathrm{s}$ üzerine direk etkili olurken $\mathrm{CO}_{2}$ su ile birleșerek karbonik asit meydana getirmektedir. Bu reaksiyonlar ise besin toprakta bulunan besin elementlerinin yarayıșılığının artmasında önemlidir. Ekimle birlikte toprağa uygulanan BK+ÇG uygulamasının 
Çizelge 2. Uygulamaların bașakların besin elementi içeriği üzerine etkisi

Table 2. Effect of treatments on nutrient contents of grain

\begin{tabular}{|c|c|c|c|c|c|}
\hline Uygulama & $\mathrm{N}(\% \mathrm{DW})$ & $\mathrm{P}(\% \mathrm{DW})$ & $\mathrm{K}(\% \mathrm{DW})$ & Ca (\% DW) & $\mathrm{Mg}(\% \mathrm{DW})$ \\
\hline SK & $1.79 \mathrm{~b}$ & $0.24 \mathrm{a}$ & $0.54 \mathrm{~b}$ & 0.091 & 0.140 a \\
\hline $\mathrm{BK}+\mathrm{CG}$ & 2.32 a & 0.25 a & 0.68 a & 0.081 & $0.128 \mathrm{~b}$ \\
\hline $\mathrm{L}$ & 2.23 a & $0.20 \mathrm{~b}$ & $0.53 \mathrm{~b}$ & 0.076 & $0.128 \mathrm{~b}$ \\
\hline K & $1.94 \mathrm{~b}$ & $0.22 \mathrm{ab}$ & $0.52 \mathrm{~b}$ & 0.077 & $0.126 \mathrm{~b}$ \\
\hline P değeri & $P<0.01$ & $P<0.05$ & $P<0.01$ & Ö.D & $P<0.05$ \\
\hline Uygulama & $\mathrm{Fe}\left(\mu \mathrm{g} \mathrm{g}^{-1} \mathrm{DW}\right)$ & $\mathrm{Cu}\left(\mu \mathrm{g} \mathrm{g^{-1 } \mathrm { DW } )}\right.$ & $\operatorname{Mn}\left(\mu \mathrm{g} \mathrm{g}^{-1} \mathrm{DW}\right)$ & $\mathrm{Zn}\left(\mu \mathrm{g} \mathrm{g}^{-1} \mathrm{DW}\right)$ & \\
\hline SK & $20.8 c$ & 2.24 & 10.59 & 20.58 & \\
\hline $\mathrm{BK}+\mathrm{CG}$ & 27.2 a & 2.29 & 11.27 & 20.76 & \\
\hline L & $24.8 \mathrm{~b}$ & 1.78 & 11.43 & 21.90 & \\
\hline K & $23.9 \mathrm{~b}$ & 2.09 & 11.07 & 22.36 & \\
\hline P değeri & $P<0.01$ & Ö.D & Ö.D & Ö.D & \\
\hline
\end{tabular}

SK: sulu kükürt, BK: bentonitli kükürt, ÇG: çiftlik gübresi, L: leonardit, K: kontrol

yaklașlk 6 ay sonra kontrole göre $\mathrm{pH}$ üzerine bir etkisinin olduğu tespit edilmiștir. Ayrıca BK'nın çiftlik gübresi ile birlikte uygulanması $\mathrm{pH}$ üzerinde de olumlu etkisinin olduğu düșünülmektedir. Schoenau ve Davis (2006) katı çiftlik gübresinin SIVı çiftlik gübrelerinden daha yüksek oranda organik madde içerdiğini ve toprağa uygulandığı zaman asidik materyal eklendiğinde $\mathrm{H}^{+}$iyonlarını tutarak, alkali materyal eklendiği zaman $\mathrm{H}^{+}$ iyonlarını serbest bırakarak $\mathrm{pH}$ düzenleyici olarak görev yaptığını yani nötürleștirme $(\mathrm{pH}=7)$ özeliği gösterdiğini belirtmiștir.

Toprak pH'sının mikro elementler içinde en çok Fe ve Mn üzerine etkili olduğu bilinmektedir. Uygulamaların dönemlere göre toprakların Fe ve $\mathrm{Mn}$ içerikleri üzerine etkisi incelendiğinde $\mathrm{pH}$ değerlerine doğru orantılı olarak bir değișim izlemiștir. İlk iki dönemde uygulamalar arasında istatistiksek olarak bir fark bulunmaz iken 3 . dönemde $\mathrm{pH}$ değerinde gerçekleșen azalmaya karșilık Fe ve Mn değerinde bir artıș gerçekleșmiștir. $\mathrm{Bu}$ artıș Mn için istatistiksel olarak önemi olurken Fe için olmamıștır (Çizelge 1). Her iki element için de $\mathrm{pH}$ değerinin en düșük olduğu $\mathrm{BK}+C, G$ uygulamasında en yüksek değerler elde edilmiștir. Bunu Mn için SK uygulaması Fe için L uygulaması takip etmiștir. 2. dönemde bütün uygulamaların birbiri ile karșılaștırıldığı varyans analizinde önemli olmayan Fe, her uygulamanın kontrole göre ayrı olarak kıyaslandığı "kontrast analizinde" \%5 seviyesinde önemli ve düșük olduğu görülmüștür. $M n$ için sadece 3 . dönemde $B K+C ̧ G$ uygulamasından elde edilen değerler kontrole göre hem yüksek hem de \%5 düzeyinde önemli olmuștur (Çizelge 3). Fe ve Mn'nin hareketliliği toprak $\mathrm{pH}$ 'sı tarafından kuvvetli bir șekilde

Çizelge 3. Bazı toprak özelliklerinde kontrol uygulamasına göre diğer uygulamaların önem seviyeleri

Table 3. Significant levels of other applications according to the control treatment at some soil properties

\begin{tabular}{|c|c|c|c|c|c|c|c|}
\hline Uyulama & Dönem & $\mathrm{EC}\left(\mathrm{dS} \mathrm{m}^{-1}\right)$ & $\mathrm{pH}$ & Fe (ppm) & $\mathrm{Mn}$ (ppm) & $\mathrm{Cu}$ (ppm) & Zn (ppm) \\
\hline SK & & 0.339 & 0.206 & 0.894 & 0.636 & 0.275 & 0.006 \\
\hline $\mathrm{BK}+\mathrm{CG}$ & 1 & 0.547 & 0.755 & 0.702 & 0.271 & 0.541 & 0.310 \\
\hline $\mathrm{L}$ & & 0.193 & 0.827 & 0.772 & 0.215 & 0.459 & 0.398 \\
\hline SK & & 0.130 & 0.549 & 0.305 & 1.000 & 0.285 & 0.136 \\
\hline $\mathrm{BK}+\mathrm{CG}$ & 2 & 0.878 & 0.529 & 0.042 & 0.242 & 0.010 & 0.106 \\
\hline $\mathrm{L}$ & & 0.873 & 0.358 & 0.225 & 0.866 & 0.553 & 0.636 \\
\hline SK & & 0.033 & 0.936 & 0.346 & 0.594 & 0.391 & 0.056 \\
\hline $\mathrm{BK}+\mathrm{CG}$ & 3 & 0.552 & 0.010 & 0.353 & 0.035 & 0.630 & 0.159 \\
\hline $\mathrm{L}$ & & 0.458 & 0.322 & 0.696 & 0.549 & 0.772 & 0.585 \\
\hline
\end{tabular}

SK: sulu kükürt. BK: bentonitli kükürt. ÇG: çiftlik gübresi. L: leonardit. K: kontrol 
Çizelge 4. Bașakların besin elementi içeriğinde kontrol uygulamasına göre diğer uygulamaların önem seviyeleri

Table 4. Significant levels of other applications according to the control treatment at nutrient contents of grain

\begin{tabular}{lccccc}
\hline Uygulama & $\mathrm{N}(\% \mathrm{DW})$ & $\mathrm{P}(\% \mathrm{DW})$ & $\mathrm{K}(\% \mathrm{DW})$ & $\mathrm{Ca}(\% \mathrm{DW})$ & $\mathrm{Mg}(\% \mathrm{DW})$ \\
\hline SK & 0.226 & 0.108 & 0.653 & 0.053 & 0.003 \\
$\mathrm{BK}+\mathrm{CG}$ & 0.016 & 0.084 & 0.001 & 0.542 & 0.575 \\
$\mathrm{~L}$ & 0.036 & 0.169 & 0.818 & 0.877 & 0.528 \\
\hline Uygulama & $\mathrm{Fe}\left(\mu \mathrm{g} \mathrm{g}^{-1} \mathrm{DW}\right)$ & $\mathrm{Cu}\left(\mu \mathrm{g} \mathrm{g^{-1 } \mathrm { DW } )}\right.$ & $\mathrm{Mn}\left(\mu \mathrm{g} \mathrm{g}^{-1} \mathrm{DW}\right)$ & $\mathrm{Zn}(\mu \mathrm{g} \mathrm{g} \mathrm{DW})$ & \\
\hline SK & 0.012 & 0.737 & 0.535 & 0.218 & \\
BK+CG & 0.012 & 0.655 & 0.799 & 0.221 & \\
$\mathrm{~L}$ & 0.372 & 0.478 & 0.647 & 0.713 & \\
\hline
\end{tabular}

SK: sulu kükürt. BK: bentonitli kükürt. ÇG: çiftlik gübresi. L: leonardit. K: kontrol

etkilenmektedir. Örneğin Scianna (2000) toprak pH'sının 1 birim değișmesine karșlık $\mathrm{Fe}^{+3}$ ün aktivitesinde 1000 kat $\mathrm{Fe}^{+2}$ 'nin aktivitesinde 100 kat değișme olduğunu bildirmiștir.

BK+ÇG uygulamasında 1. dönemde yüksek seviyede olan Zn, 3. dönemde en düșük seviyelerde olduğu görülmüștür (Çizelge 1). BK+ÇG uygulaması ile diğer uygulamalara göre toprak organik maddesinde sezon içinde geçici de olsa bir artıșın olması beklenmektedir. Organik maddenin ayrıșması ile toprakta bitkiye elverișli olarak bulunan Zn'nin organik madde tarafından tutulduğu düșünülmektedir. Shuman (1988), toprak yüzeyinde organik madde miktarının artmasının Zn eksikliğine neden olduğunu bildirmiștir. Benzer durum Cu'da da gerçekleșmiștir. 2. dönem alınan topraklarda en düșük $\mathrm{Cu}$ değerleri $\mathrm{BK}+C \mathrm{G}$ uygulamasından elde edilmiștir (Çizelge 1).

Varyans analizine göre uygulamalar arasında bașak tanelerinin besin elementi içeriğinde de önemli değișmeler olmuștur ve $\mathrm{N}, \mathrm{P}, \mathrm{K}, \mathrm{Mg}$ ve Fe yönünden uygulamalar arasında farklılıklar bulunmuștur. En yüksek N, P, K ve Fe değerleri $\mathrm{BK}+C, G$ uygulamasından elde edilmiștir. Mg'da durum farklı olmuș ve SK uygulaması öne çıkmıștır. Tanelerin N, P, K ve Fe içerikleri ortalama olarak sirasılyla \% 1.79-2.32, \%0.20-0.25, \%0.52-0.68 ve 20.8-27.2 ppm arasında değișmiștir (Çizelge 2). BK+ÇG uygulamasında yüksek değerlerin elde edilmesi ÇG'den kaynaklandığı düșünülmektedir. Schoenau ve Davis (2006) çiftlik gübrelerinin toprağa sadece besin elementi sağlamakla kalmadığını aynı zamanda uygun toprak koșullanın olușmasına da katkıda bulunduğunu bildirmiștir. Bașak tanelerinin besin içerikleri "kontrast analizine" tabi tutulduğunda "varyans analizinde" $\% 1$ düzeyinde önemli olan ve aynı grupta yer alan $B K+C, G$ ve $L$ uygulamalarından sadece $B K+C, G$ uygulamasının K uygulamasına göre önemli olduğu tespit edilmiștir. Varyans analizinde $P$ yönünden birbirinden $\% 5$ seviyesinde önemli olan uygulamalar "kontrast analizinde" kontrole göre önemli olmadığı görülmüștür. Bașak tanelerinin K içeriği hem varyans hem de kontrast analizinde $\% 1$ seviyesinde BK+ÇG uygulamasında, Mg içeriği ise SK uygulamasında yüksek olduğu görülmüștür. Fe için her iki analiz için de sonuç değișmemiș kontrole göre BK+ÇG uygulaması \%1 düzeyinde önemli olurken SK uygulaması \%1 seviyesinde düșük olmuș ve $L$ uygulaması $K$ uygulamasına göre değișiklik göstermemiștir (Çizelge 4).

\section{SONUÇLAR}

Calıșmada kullanılan materyaller özellik ve kullanılan miktar bakımından birbirinden farklılık göstermektedir. Bu yüzden sonuçların değerlendirilmesinde "Varyans analizine" ek olarak "kontrast analizi" de yapılımıștır. Bu șekilde her bir ürünün $\mathrm{K}$ uygulamasına göre etkili olup olmadığı da tespit edilmiștir. Hem varyans hem de kontrast analizine göre BK+ÇG uygulamasının toprakların $\mathrm{pH}$ ile $\mathrm{Mn}$, bașak tanelerinin $\mathrm{N}$, K, ve Fe içerikleri üzerine olumlu etkisinin olduğu tespit edilmiștir. Toprak pH'sının düșürülmesinde SK ve L uygulamalarının herhangi bir etkisi olmadığı gibi tanelerin besin elementi içeriğinde genel olarak bir artıș sağlamamıștır. BK+ÇG uygulaması ile arpanın besin elementi değerinin artması sağlamıștır. Bașakların besin elementi değerinin artması hayvan beslenmesinde önemli olduğu düșünülmektedir. BK+ÇG uygulaması bu olumlu etkisinin yanında verimde de \%20 oranında bir artıș sağlamıștır. Bu olumlu etkileri ile birlikte BK+ÇG maliyeti yüksek olan bir uygulamalıdır. Bu yüzden ekonomik analizler bu uygulamanın hububat tarımında kullanımını kısıtlayabileceği düșünülmektedir. 


\section{KAYNAKLAR}

Anonymous (2013). Effects of Manure and fertilizer on soil fertility and soil quality. Manitoba, p. 68. (http://www. gov.mb.ca/agriculture/environment/nutrient-management/ pubs/).

Anonymous (1990). Management of Gypsiferous Soils. FAO Soils Bulletin no:62, Food and Agriculture Organization of the United Nations, Rome, p. 81.

Chang C, Sommerfeldt TG, Entz T (1991). Soil Chemistry after eleven annual applications of cattle feedlot manure. J. Environ. Qual., 20:475-480.

Güçdemir IH (2006). Türkiye gübre ve gübreleme rehberi. Güncelleștirilmiș ve genișletilmiș 5. Baskı. Tarımsal Araștırmalar Genel Müdürlüğü, Toprak ve Gübre Araștırma Enstitüsü Müdürlüğü Yayınları, Genel Yayın No: 231. Ankara, p. 424.

Güneri M, Mısırlı A, Yokaș İ, Yağmur B (2012). Valensiya portakal çeșidinde kükürt, jips, amonyum sülfat ve sitrik asit uygulamalarının bitki besin elementleri içeriklerine etkileri. Ege Üniversitesi Ziraat Fakültesi Dergisi, 49(1): 83-92.

Kaymak MR (2011). Kükürt'ün toprak ve bitki besleme yönünden önemi. Yüksek Lisans Tezi, Çukurova Üniversitesi, Fen Bilimleri Enstitüsü, Toprak Bilimi ve Bitki Besleme Anabilim Dalı, Adana.

Longstroth M (2017). Lowering the soil ph with sulfur. Courstesy of MSU Extension (news.msue.msu.edu).

Mickelbart MV, Stanton KM, Hawkins S, Camberato J (2017). Lowering soil $\mathrm{pH}$ for horticulture crops. purdue extension publication HO-241-W, Commercial Greenhouse and Nursery Production (mww. the-education-store.com).

McCauley A, Jones C, Olson-Rutz K (2017). Soil pH and organic matter. Nutrient Management Module No: 8, Montana State University Extension, p. 16.
Mohd-Aizat A Mohamad-Roslan MK, Sulaiman WNA Karam DS (2014). The relationship between soil pH and selected soil properties in 48 years logged-over forest. International Journal of Environmental Sciences, 4(6):11291140.

Patel PC, Patel MS, Kalyanasundaram NK (1997). Effect of foliar spray of Iron and sulphur on fruit yield of chlorotic acid lime. Journal of the Indian Society of Soil Science, 45(3):529533.

Ryan J, Estafan G, Rashid A (2001). Soil and plant analysis laboratory. Manual 2nd ed. ICARDA and NARS, Aleppo, Syria, pp. 135-140.

Scianna S (2000). Iron (Fe) chlorosis in plants. HortNote No. 7. (http://Plant-Materials.nrcs.usda.gov).

Schoenau JJ, Davis JG (2006). Optimizing soil and plant responses to land applied manure nutrients in the great plains of North America. Canadian Journal of Soil Science, 86: 587-595.

Shuman LM (1988). Effect of Organic Matter on the Distribution of Manganese, Copper, Iron, and Zinc in Soil Fractions. Soil Science, 146: 192-198.

Ülgen N, Yurtsever N (1995). Türkiye gübre ve gübreleme rehberi (4. Baskı). T.C. Bașbakanlık Köy Hizmetleri Genel Müdürlüğü Toprak ve Gübre Araștırma Enstitüsü Müdürlüğü Yayınları. Genel Yayın No: 209. Teknik Yayınlar No: T.66, Ankara, p. 230.

Vossen $\mathrm{P}$ (2017). Changing $\mathrm{pH}$ in soil. University of California, Cooperative Extension. (http://vric.ucdavis.edu/ pdf/Soil/ChangingpHinSoil.pdf). 